\title{
COMPARATIVE LIFECYCLE ASSESSMENT OF APPLE PACKAGING
}

\author{
Janusz Majewski, Eng $\mathrm{PhD}^{1}$; Agnieszka Sobolewska, Eng $\mathrm{PhD}^{2}$
}

Faculty of Economic Sciences, Warsaw University of Life Sciences - SGGW

\begin{abstract}
In the paper was presented a comparative analysis of the impact on the environment of the life cycle assessment of boxes made of polypropylene, re-HDPE and cardboard, which are used to transport of dessert apples. For this purpose, the SimaPro 7.1 computer program and attached databases were used. The calculations were made for 48 trading circulations. The obtained results indicate that the biggest negative impact on the environment among the analysed packaging was caused by cardboard boxes. Also packaging from recycled material (re-HDPE) is less friendly to environment than boxes made from new polypropylene. The estimated environmental impact of polypropylene boxes was $4.42 \mathrm{Pt}$ (eco-indicator point), for reHDPE and cardboard packaging it was 7.5 and $19.7 \%$ higher, respectively. The most important factor for the differences between the boxes was the durability of the packaging and the eventual need for multiple repeats of production phase, which include the acquisition of raw materials and processes related to the manufacturing of products.
\end{abstract}

Keywords: environment, packaging, life cycle assessment (LCA)

JEL codes: Q53, Q56

\section{INTRODUCTION}

Every human activity causes social, economic and/or ecological effects. In production and service spheres impacts to environment play an increasingly role, which can be associated with deteriorating its quality in the world. This situation indicates the need to analyse and assess the ecological effects of the production (or service) process, taking into account the entire life cycle of the produced thing (service). In many cases, it is also justified to analyse and evaluate only the production process itself or only its individual phases. This type of research is used to identify the processes or phases of product exploitation that have the greatest negative impact on the natural environment. Their identification allows for implementation of innovative changes to reduce pressure on the natural environment. Thanks to this, it is possible to use more renewable and nonrenewable resources and in this way to implemented sustainable production and consumption of goods and services.

The Life Cycle Assessment (LCA) is a tool for analysing, assessing and comparing the impact on the natural environment of production and use of goods (and services). The study presents results regarding the LCA for three types of packaging used in wholesale trade in apples in Poland. The choice

\footnotetext{
${ }^{1}$ Corresponding author: Nowoursynowska 166, 02-787 Warszawa, Poland, janusz majewski@sggw.pl, +4822 5934112

${ }^{2}$ Corresponding author: Nowoursynowska 166, 02-787 Warszawa, Poland, Agnieszka_Sobolewska@sggw.pl, +4822 5934108
} 
of apple packaging was due to the importance of these fruits. Apple production in Poland increased from over 2.1 million tons annually average in 2006-2010 to over 3.5 million tons in 2016. Their share in the volume of fruit tree production was at that time $85-89 \%$ (GUS, 2007). Poland at the end of the first decade of the 21 st century became the largest producer of apples in the EU (Kracinski, 2015). In 2016, Poland's share in apples production in the EU was almost $30 \%$. Poland is the largest apple exporter in the EU (Kowalska, 2016). It caused that problem of apple packaging is important from Polish point of view.

\section{LIFE CYCLE ASSESSMENT}

Life cycle assessment is a technique used to analyse the environmental hazard associated with a product throughout its lifetime, that is, from obtaining the raw material for production, through distribution, use, until final liquidation, that is 'from the cradle to the grave'. The LCA consists of four stages: definition of goal and scope, life cycle inventory analysis, life cycle impact assessment and interpretation of results (Saraiva et al., 2016; Sala et al., 2017).

The LCA method for the first time was used in the 1960s to assess energy production. The study was continued in the following years. One of the first research using LCA concerned the assessment of direct and indirect emissions of waste generated during production processes (Ayres, 1995). The method development in subsequent years meant that it was used in many fields (Accorsi, Versari and Manzini, 2015; Saleh, 2016). As a result of the need to integrate the life cycle assessment with social aspects, a social life cycle assessment (SLCA) was developed in the first decade of the 21 st century. It was a way of assessing the social and socio-economic aspects of products and their positive and negative impacts in the full life cycle (Petti, Serreli and Di Cesare, 2018).

The importance of LCA is related to both: macro and micro analyses. On the macro scale, it allows to define a concept aimed at sustainable production and consumption, because these patterns are factors that have a significant impact on the environment.
Assessment and improvement of supply chains allows minimizing the negative effects on the environment (Notarnicola et al., 2017). It is a process without end. On the other hand, on the micro scale, LCA allows the assessment of technologies used, and thus facilitates their selection, so that the negative impact on the environment is as small as possible (Walker et al., 2018).

In order to assess the impact on the natural environment during the life cycle assessment of a specific product or service, specialized programs may be used. There are two computer programs commonly used in the world: SimaPro and GaBi (Herrmann and Moltesen, 2015; Starostka-Patyk, 2015). Also in the LCA research published in the years 2010-2013, the above-mentioned programs were mainly used. The frequency use of SimaPro program was about 4 times more in published research works than the GaBi program (Speck et al., 2015).

The scientific research on the impact of the life cycle assessment regarding the production and distribution of apples have not been conducted on a larger scale. In the literature, we found a publication on the environmental impact of apple orchards used in three systems: conventional, integrated and ecological (Goossens et al., 2017) and the paper were the environmental impact of apple supply chain and apple waste was evaluated Romanians (Ghinea, 2017). In another paper, a study was carried out on the environmental impact of packaging used in the apple trade in Poland. Two types of packaging were used for comparisons, i.e. a plastic and cardboard box (Manteuffel-Szeoge and Sobolewska, 2009).

The flow pattern of raw materials, intake and emission of substances into the environment in the life cycle assessment of the box used for transporting apples was shown in Figure 1. The raw materials taken from the environment are processed into materials that are used for the production of packaging. New boxes are transported to the warehouse where the use phase begins. Mostly used products are recycled, they are utilized to a small extent. The raw material obtained from recycling can be re-used for the production of boxes. At each of the described phases there is a collection and emission of substances to the environment. 


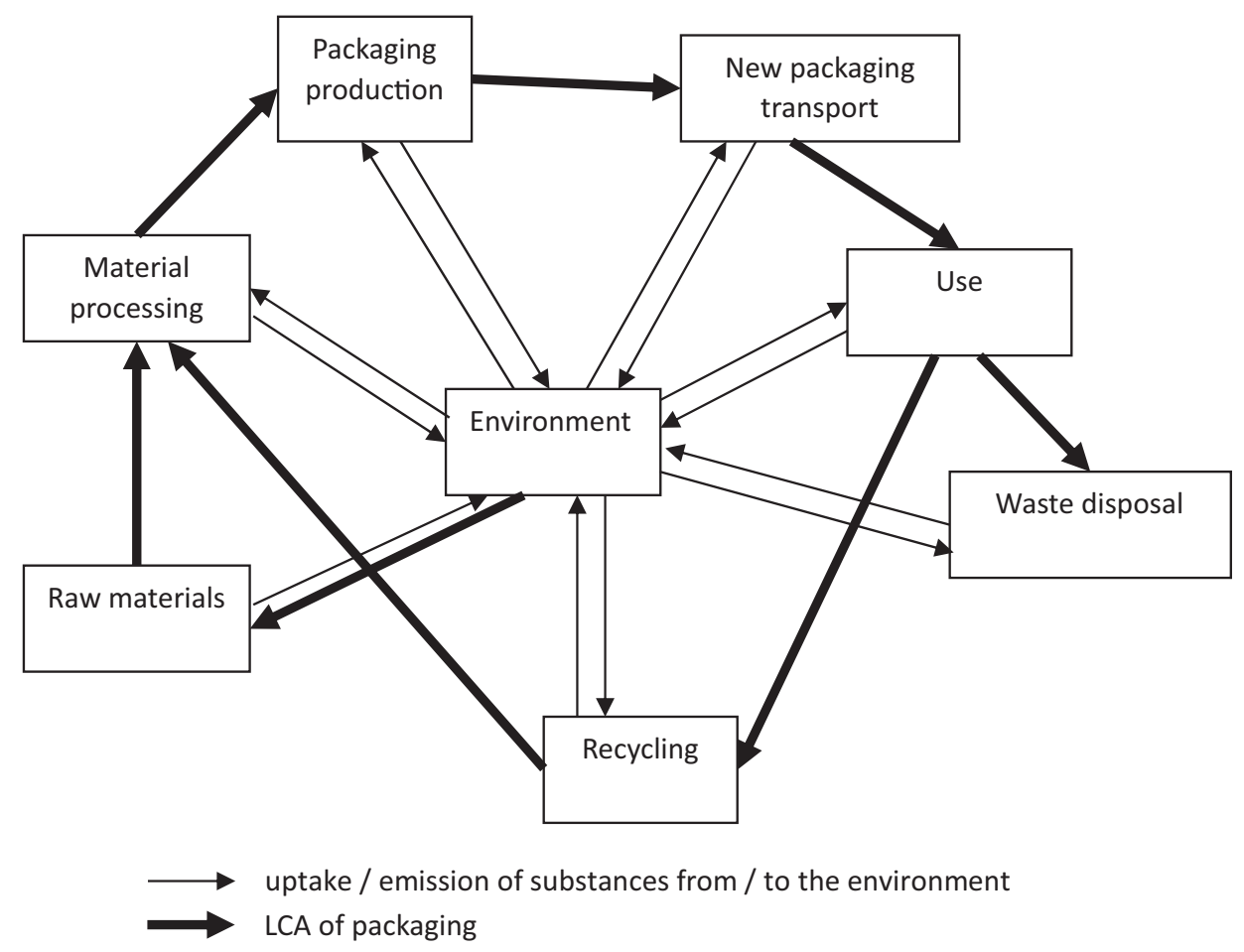

Figure 1. Phases of the boxes life cycle assessment and their impact on the environment Source: own elaboration based on Ciambrone (1997), Ganczewski et al. (2014).

\section{MATERIALS AND MATERIALS}

The aim of the work is a comparative assessment of the impact on the environment of the life cycle assessment of various types of packaging used in wholesale trade in dessert apples. The tests included boxes made of polypropylene (polypropylene), HDPE recycled (re-HDPE) and cardboard with alkyd varnish (cardboard). The capacity of the analysed boxes was $12 \mathrm{~kg}$ of apples. Due to the properties of the material from which researched boxes were made, there were characterized by different durability. In the tests, it was assumed that the cardboard box is one-off, with re-HDPE performing 16 commercial turnovers, and polypropylene 48 turnovers.

A life cycle model was built for each of the boxes. It includes the phase of production, use and disposal scenario. In the first phase, the quantities of individual raw materials necessary to make boxes were determined. It was $1.5 \mathrm{~kg}$ of polypropylene, $1.4 \mathrm{~kg}$ of re-HDPE and $0.61 \mathrm{~kg}$ of cardboard and 0.01 of alkyd varnish for a cardboard box. Then, the production processes of individual packages were defined. In the use phase, the distances between the individual links of the logistic chain, modes of transport and forklifts on the premises of the warehouse and logistic platform were taken into account. It was assumed that after using the analysed products they will mostly be recycled, only a small part will go to households (Table 1).

In addition, the life cycle assessment of each box was related to the life cycle of polypropylene spacers securing apples in boxes and packaging film made of LDPE wrapping the box during transport on trays.

The calculations were made in the SimaPro 7.1 program using the databases attached to it. In order to determine a single synthetic indicator of the environmental impact of the life cycle assessment of boxes made of polypropylene, re-HDPE and cardboard, the Eco-indicator 99 Europe E/E methodology was used. The obtained results are expressed in impact points $(\mathrm{Pt})$ appointed in accordance with the 
Proceedings of the 2018 International Scientific Conference 'Economic Sciences for Agribusiness and Rural Economy' No 2, Warsaw, 7-8 June 2018, pp. 340-346

Table 1. Disposal scenarios of compared boxes

\begin{tabular}{|l|c|c|c|}
\hline \multirow{2}{*}{ Disposal scenario } & \multicolumn{2}{|c|}{ The material used to the box's production } \\
\cline { 2 - 4 } & polypropylene & re-HDPE & cardboard \\
\hline Recycling (\%) & 99 & 99 & 90 \\
\hline Household waste (\%) & 1 & 1 & 10 \\
\hline
\end{tabular}

Source: own study.

adopted method (Eco-indicator 99 Europe E/E). This is a commonly used method, the description of which can be found in the works of Vogtlander, Brezet and Hendriks (2001), Dreyer, Niemann and Hauschild (2003) and Bovea and Gallardo (2006).

\section{RESULTS AND DISCUSSION}

The analysis shows that the use of cardboard boxes for the transport of dessert apples will have a greater negative impact on the environment than in the case of plastic boxes (Fig. 2). Also, packaging made of recycled plastic (re-HDPE) in the analysed case turned out to be more harmful to the environment in relation to the new polypropylene. Due to the different durability of the material from which the packages covered by the tests were made, one life cycle of the polypropylene box was compared with 3 cycles of reHDPE box and 48 cardboard boxes. Finally, for packaging made of cardboard, 5.29 Pt of environmental impact was obtained, while for a box of re-HDPE 4.75 $\mathrm{Pt}$ and polypropylene $4.42 \mathrm{Pt}$.

Considering the various phases of the life cycle assessment of plastic (polypropylene and re-HDPE boxes) and cardboard packaging, we can conclude that more than $50 \%$ share of the negative environmental impact was appeared in the production phase (Figs. 2 and 3). The production of one polypropylene box had an impact of $2.33 \mathrm{Pt}$, while for a re-HDPE box it was $0.9 \mathrm{Pt}$ and for cardboard box $0.06 \mathrm{Pt}$. After taking into account the durability of individual packaging for the production of a box with a re-HDPE obtained $2.73 \mathrm{Pt}$, and for the cardboard box $2.96 \mathrm{Pt}$. At the same time, the obtained results show that the main factor affecting the differences in the environmental impact of the analysed life cycles assessment is the process of obtaining raw materials and producing products. Although the production of 1 box of re-HDPE or cardboard causes a much smaller negative impact on the environment than in the case of

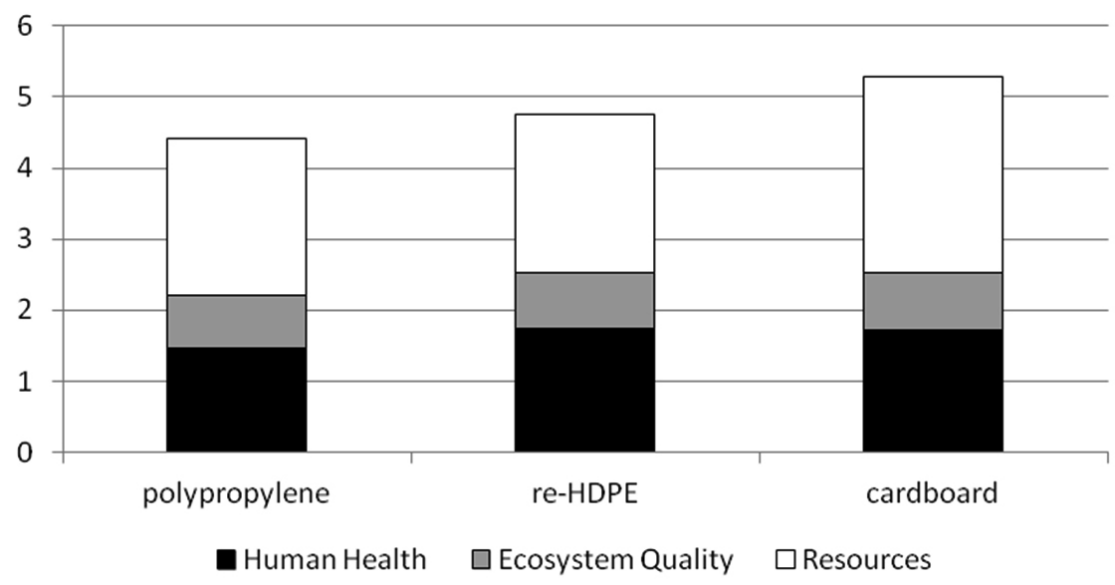

Figure 2. The environmental impact of the life cycle of compered boxes used to apples' transport Source: own study. 
Proceedings of the 2018 International Scientific Conference 'Economic Sciences for Agribusiness and Rural Economy' No 2, Warsaw, 7-8 June 2018, pp. 340-346

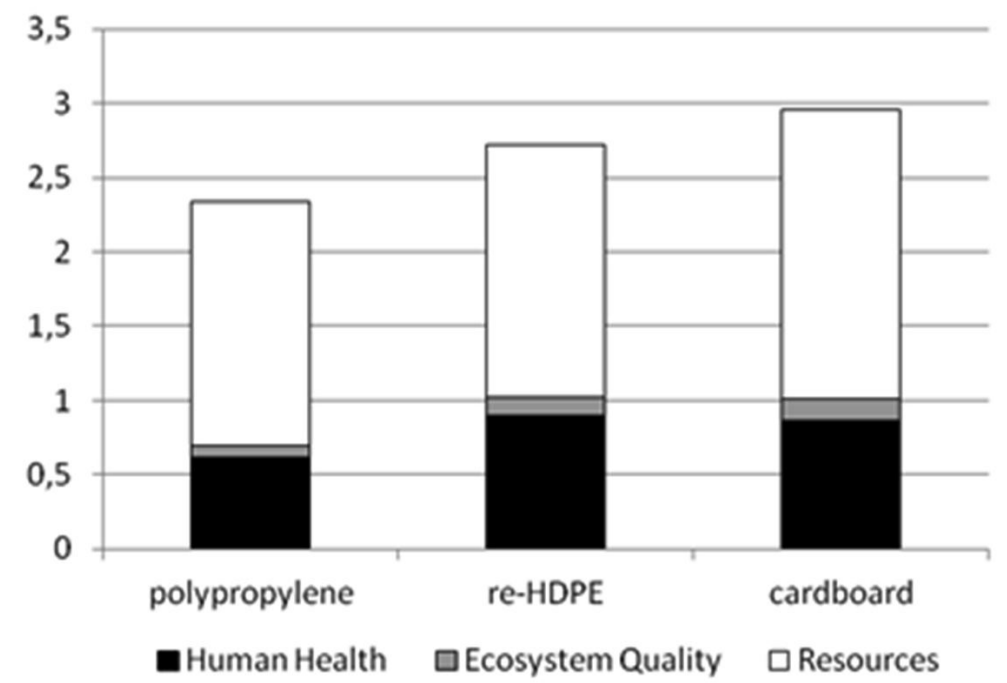

Figure 3. The environmental impact of the LCA production phase of boxes used to apples' transport Source: own study.

polypropylene, the necessity of repeated repetition of this process causes that these packaging have a greater negative impact on the environment.

Among the three categories of impact (human health, raw materials and ecosystem quality), the largest (about 50\%) of the raw materials (mainly fossil fuels) taken from the environment are essential, both in the production process and during transport during the exploitation phase. The analysed life cycles assessment in the smallest degree (about 16\%) affect the quality of ecosystems contributing to the destruction of the ozone layer, radioactive background growth, terrain occupancy, climate change, acidification and environmental eutrophication (Fig. 4).



Figure 4. Impact on the natural environment by categories of the LCA of boxes used for apples' transport Source: own study. 
There is a clear increase in the impact in the category of ecosystem quality in the entire life cycle of the boxes compared to the production phase. This is a consequence of the need to build roads and road infrastructure necessary for transporting boxes during their use. In the human health category, the issue of respirators inorganics has the greatest impact. Regardless of the type of material used for the production of boxes, the percentage share of individual categories in the total environmental impact is similar.

\section{CONCLUSIONS}

The conducted research has shown that the use of the LCA method in relation to packaging made of various materials allows to indicate the most environmental friendly solutions and to determine the factors affecting the obtained results. From the analysed packages made of cardboard, re-HDPE and polypropylene, the greatest negative impact on the environment is caused by the use of cardboard boxes for the apple transport. Boxes made of recycled material, due to their lower durability, were also less environmentally friendly than polyethylene boxes. The durability of packaging and the possible need to repeat the production phase, including obtaining raw materials and processes related to the production of boxes, are of the greatest importance for the differences between the boxes. If the cardboard boxes were used to transport apples twice, their impact on the environment would decrease by about $25 \%$. In this case, these boxes would have the least negative impact on the environment.

\section{REFERENCES}

1. Accorsi, R., Versari, L., Manzini, R. (2015). Glass vs. Plastic: Life Cycle Assessment of Extra-Virgin Olive Oil Bottles across Global Supply Chains. Sustainability, 7 (3), pp. 2818-2840.

2. Ayres, R.U. (1995). Life Cycle Analysis: A Critique. Resources, Conservation and Recycling, 14, pp. 199$-223$.

3. Bovea, M.D., Gallardo, A. (2006). The Influence of Impact Assessment Methods in Materials Selection for Eco-Design. Material and Design, 27 (3), pp. 209-215.

4. Ciambrone, D.F. (1997). Environmental Life Cycle Analysis. CRC Press, Boca Raton.
5. Dreyer, L.C., Niemann, A.L., Hauschild, M.Z. (2003). Comparison of Three Different LCIA Methods: EDIP97, CML2001 and Eco-indicator 99. The International Journal of Life Cycle Assessment, 8 (4), pp. 191-200.

6. Ganczewski, G., Nowakowski, K., Grochocka, M., Wójcik, K. (2014). Ocena cyklu życia (LCA) wybranych opakowań do pomidorów [Life cycle assessment (LCA) of selected tomato packaging]. Chemik, 68 (8), pp. 692-702.

7. Ghinea, C. (2017). Assessment of Environmental Impact of Food Loss: Case Study Apple Fruits. Food and Environment Safety Journal, 16 (1), pp. 21-28.

8. Goossens, Y., Annaert, B., De Tavernier, J., Mathijs, E., Keulemans, W., Geeraerd, A. (2017). Life Cycle Assessment (LCA) for Apple Orchard Production Systems Including Low and High Productive Years in Conventional, Integrated and Organic Farms. Agricultural Systems, 153, pp. 81-93.

9. GUS (2018). Rocznik Statystyczny Rolnictwa 2017 [Statistical Yearbook of Agriculture 2017]. Dział Wydawnictw Statystycznych GUS, Warszawa.

10. Herrmann, I.T., Moltesen, A. (2015). Does it matter which Life Cycle Assessment (LCA) Tool You Choose? - a Comparative Assessment of SimaPro and GaBi. Journal of Cleaner Production, 86, pp. 163-169.

11. Kowalska, A. (2016). Międzynarodowa konkurencyjność polskiego sektora owocowego po przystapieniu do Unii Europejskiej [International Competitiveness of Polish Fruit Sector Following the Accession to the European Union]. Zeszyty Naukowe SGGW w Warszawie. Problemy Rolnictwa Światowego, 16 (2), pp. 176-185.

12. Kracinski, P. (2015). Handel zagraniczny jabłkami w UE w kontekście rosyjskiego embargo [The EU Foreign Trade of Apples in the Context of the Russian Embargo]. Zeszyty Naukowe SGGW w Warszawie. Problemy Rolnictwa Światowego, 15 (3), pp. 83-92.

13. Manteuffel-Szoege, H., Sobolewska, A. (2009). Life Cycle Analysis with Regard to Environmental Impact of Apple Wholesale Packaging. Zeszyty Naukowe SGGW w Warszawie. Problemy Rolnictwa Światowego, 6 (21), pp. 59-68.

14. Notarnicola, B., Sala, S., Anton, A., McLaren, S.J., Saouter, E., Sonesson, U. (2017). The Role of Life Cycle Assessment in Supporting Sustainable Agri-Food Systems: A Review of the Challenges. Journal of Cleaner Production, 140, Part 2, pp. 399-409.

15. Petti, L., Serreli, M., Di Cesare, S. (2018). Systematic Literature Review in Social Life Cycle Assessment. The International Journal of Life Cycle Assessment, 23, pp. 422-431. 
16. Sala, S., Anton, A., McLaren, S.J., Notarnicola, B., Saouter, E., Sonesson, U. (2017). In Quest of Reducing the Environmental Impacts of Food Production and Consumption. Journal of Cleaner Production, 140, Part 2, pp. 387-398.

17. Saleh, Y. (2016). Comparative Life Cycle Assessment of Beverages Packages in Palestine. Journal of Cleaner Production, 131, pp. 28-42.

18. Saraiva, A.B., Pacheco, E.B.A.V., Gomes, G.M., Visconte, L.LY., Bernardo, C.A., Simões, C.L., Soares, A.G. (2016). Comparative Lifecycle Assessment of Mango Packaging Made from a Polyethylene/Natural Fiber-Composite and from Cardboard Material. Journal of Cleaner Production, 139, pp. 1168-1180.

19. Speck, R., Selke, S., Auras, R., Fitzsimmons, J. (2015). Choice of Life Cycle Assessment Software Can Impact
Packaging System Decisions. Packaging Technology and Science, 28, pp. 579-588.

20. Starostka-Patyk, M. (2015). New Products Design Decision Making Support by SimaPro Software on the Base of Defective Products Management. Procedia Computer Science, 65, pp. 1066-1074.

21. Vogtlander, J.G., Brezet, H.C., Hendriks, Ch.F. (2001). The virtual eco-costs ' 99 A single LCA-based indicator for sustainability and the eco-costs-value ratio (EVR) model for economic allocation. The International Journal of Life Cycle Assessment 6(3), pp. 157-166.

22. Walker, Ch., Beretta, C., Sanjuan, N., Hellweg, S. (2018). Calculating the Energy and Water Use in Food Processing and Assessing the Resulting Impacts. The International Journal of Life Cycle Assessment, 23, pp. 824-839. 